\title{
Erratum: The use of collision detection to infer multi-camera calibration quality
}

\section{Frontiers Production Office*}

Frontiers Production Office, Frontiers, Switzerland

Keywords: error analysis, collision detection, camera calibration, accuracy, kinematics

\section{An erratum on}

The use of collision detection to infer multi-camera calibration quality

by Chong, S.-Y, Dorow, B., Ramasamy, E., Dennerlein, F, and Röhrle, O. Front. Bioeng. Biotechnol. (2015) 3:65. doi:10.3389/fbioe.2015.00065

\section{Reason for Erratum}

Due to an oversight, the name of the author Oliver Röhrle was published as Oliver Röehrle instead of Oliver Röhrle. This mistake does not change the scientific conclusions of the article in any way.

The publisher apologizes for this error.

Original article has been updated.

OPEN ACCESS

Approved by:

Bioengineering and Biotechnology Editorial Office, Frontiers, Switzerland

*Correspondence: Frontiers Production Office production.office@frontiersin.org

Specialty section:

This article was submitted to Biomechanics, a section of the journal Frontiers in Bioengineering and Biotechnology

Received: 20 August 2015 Accepted: 20 August 2015 Published: 31 August 2015

Citation: Frontiers Production Office (2015) Erratum: The use of collision detection to infer multi-camera calibration quality.

Front. Bioeng. Biotechnol. 3:134. doi: 10.3389/fbioe.2015.00134
Copyright (C) 2015 Frontiers Production Office. This is an open-access article distributed under the terms of the Creative Commons Attribution License (CC BY). The use, distribution or reproduction in other forums is permitted, provided the original author(s) or licensor are credited and that the original publication in this journal is cited, in accordance with accepted academic practice. No use, distribution or reproduction is permitted which does not comply with these terms. 